\title{
Assessment of the Biofield Energy Healing Based Test Formulation on Human Organ Health Specific Biomarkers In Vitro Assays
}

\author{
Eileen Mary Meagher ${ }^{1}$, Mahendra Kumar Trivedi ${ }^{1}$, Alice Branton ${ }^{1}$, Dahryn \\ Trivedii ${ }^{1}$, Gopal Nayak ${ }^{1}$, Mayank Gangwar ${ }^{2}$ and Snehasis Jana ${ }^{2 *}$ \\ ${ }^{1}$ Trivedi Global Inc, USA \\ ${ }^{2}$ Trivedi Science Research Laboratory Pvt Ltd, India
}

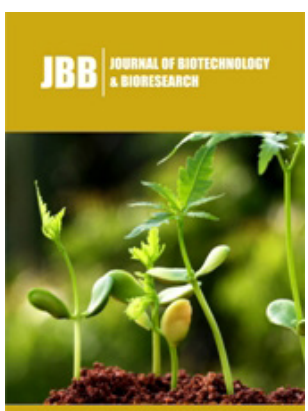

*Corresponding author: Snehasis Jana, Trivedi Science Research Laboratory Pvt Ltd, Thane-West, Maharashtra, India

Submission: 㭗June 14, 2019

Published: 㭗June 26, 2019

Volume 2 - Issue 1

How to cite this article: Eileen $M$ Mahendra K T, Alice B, Dahryn T, Gopal N, et al. Assessment of the Biofield Energy Healing Based Test Formulation on Human Organ Health Specific Biomarkers In Vitro Assays. J Biotech Biores.2(1). JBB.000529.2019.

Copyright@ Eileen Mary Meagher, This article is distributed under the terms of the Creative Commons Attribution 4.0 International License, which permits unrestricted use and redistribution provided that the original author and source are credited.

\begin{abstract}
Herbal based test formulations have been used in most of the healthcare settings since time immemorial. The present experimental cell line study was designed to evaluate the impact of the Biofield Energy Treatment on test formulation and different cell line mediums related with vital organs functioning. Cell lines that were specific to different organ systems were used in the study using standard protocols. The Test Item (TI) and specific cell line media (Med) was divided into two parts; one untreated (UT-TI) and other part received the Biofield Energy Treatment remotely by a renowned Biofield Energy Healer, Eileen Mary Meagher, USA and were labeled as the Biofield Energy Treated (BT) test formulation/media. MTT assay was used for cell viability assay, and the results showed that the test item was found non-toxic. Cytoprotective action of the test formulation showed a significant maximum restoration of cell viability by $56.8 \%$ (at $63.75 \mu \mathrm{g} / \mathrm{mL}$ ), $57.5 \%$ (at $63.75 \mu \mathrm{g} / \mathrm{mL}$ ), and $124.8 \%$ (at $1 \mu \mathrm{g} / \mathrm{mL}$ ) in the UT-Med+BT-TI, BTMed+UT-TI, and BT-Med+BT-TI groups respectively, as compared to the untreated test group in Human Cardiac Fibroblasts cells (HCF) cells, while $83.2 \%$ (at $63.75 \mu \mathrm{g} / \mathrm{mL}$ ), $93.8 \%$ (at $63.75 \mu \mathrm{g} / \mathrm{mL}$ ), and $20.6 \%$ (at $10 \mu \mathrm{g} / \mathrm{mL}$ ) improved cellular protection of human Hepatoma cells (HepG2) cells in the UT-Med+BTTI, BT-Med+UT-TI, and BT-Med+BT-TI groups respectively, as compared to the untreated test group. In addition, cytoprotective activity in adenocarcinoma human alveolar basal epithelial cells (A549) showed improved cell viability by $11.3 \%$ (at $25.5 \mu \mathrm{g} / \mathrm{mL}$ ), $82.7 \%$ (at $63.75 \mu \mathrm{g} / \mathrm{mL}$ ), and $113.9 \%$ (at $25.5 \mu \mathrm{g} / \mathrm{mL}$ ) in the UT-Med+BT-TI, BT-Med+UT-TI, and BT-Med+BT-TI groups respectively, as compared to the untreated test group. MG-63 cells were used for estimation of ALP activity, which was highly increased by $59.8 \%$ (at $0.1 \mu \mathrm{g} / \mathrm{mL}$ ), $269.7 \%$ (at $0.1 \mu \mathrm{g} / \mathrm{mL}$ ), and $105.7 \%$ (at $0.1 \mu \mathrm{g} / \mathrm{mL}$ ) in the UT-Med+BT-TI, BT-Med+UT-TI, and BT-Med+BT-TI groups respectively, as compared to the untreated test group. Besides, Ishikawa cells showed maximum increased ALP activity by $94.8 \%$ at $10 \mu \mathrm{g} / \mathrm{mL}$ in the BT-Med+UT-TI group as compared to the untreated group. The maximum percent cellular protection of HCF (heart) cells (decreased of LDH activity) was significantly increased by $48.8 \%$ (at $1 \mu \mathrm{g} / \mathrm{mL}$ ), $62.9 \%$ (at $10 \mu \mathrm{g} / \mathrm{mL}$ ), and $103 \%$ (at $1 \mu \mathrm{g} / \mathrm{mL}$ ) in the UT-Med+BT-TI, BT-Med+UT-TI group, and BT-Med+BT-TI groups respectively, as compared to the untreated test group. Alanine Amino Transferase (ALT) in terms of percent protection of HepG2 (liver) cells (decreased of ALT activity) was reported at $63.75 \mu \mathrm{g} / \mathrm{mL}$ by $74.9 \%$ and $84.9 \%$ in the BT-Med+UTTI and BT-Med+BT-TI groups respectively, as compared to the untreated test group. Cellular protection of A549 (lungs) cells (increased of SOD activity) in terms of percentage was increased by $21.7 \%$ (at $25.5 \mu \mathrm{g} / \mathrm{mL}$ ), $83.2 \%$ (at $0.1 \mu \mathrm{g} / \mathrm{mL}$ ), and $40 \%$ (at $25.5 \mu \mathrm{g} / \mathrm{mL}$ ) in the UT-Med+BT-TI, BT-Med+UT-TI, and BT-Med+BT-TI groups, respectively as compared to untreated group. Serotonin level was significantly increased by $50.8 \%$ (at $63.75 \mu \mathrm{g} / \mathrm{mL}$ ), 35.9\% (at $10 \mu \mathrm{g} / \mathrm{mL}$ ), and $49.9 \%$ (at $10 \mu \mathrm{g} / \mathrm{mL}$ ) in the UT-Med+BTTI, BT-Med+UT-TI, and BT-Med+BT-TI groups, respectively compared to untreated test group in human neuroblastoma cells (SH-SY5Y). However, the Relative Quantification (RQ) of Vitamin D Receptor (VDR) was significantly increased by $135.2 \%, 291.4 \%$, and $248.3 \%$ at $50 \mu \mathrm{g} / \mathrm{mL}$ in the UT-Med+BT-TI, BTMed+UT-TI, and BT-Med+BT-TI groups, respectively as compared to the untreated in MG- 63 cells. Thus, Biofield Energy Treated test formulation (The Trivedi Effect ${ }^{\circledR}$ ) would be significantly useful for multiple organ health that can be used against coronary artery disease, arrhythmias, congenital heart disease, cardiomyopathy, cirrhosis, liver cancer, hemochromatosis, asthma, chronic bronchitis, cystic fibrosis, osteoporosis, etc.
\end{abstract}

Keywords: The Trivedi effect ${ }^{\circledR}$; Biofield energy treatment; Organ health; Cardiac health; Liver health; Lungs health; Multiple organ failure; Bone health

\section{Introduction}

Herbal based test medicines are existed world-wide with long recorded history and its development system was based on plant science, which uses some vital plant and its parts in the formulation in order to alleviate the diseases. This is also defined as phytomedicines, and these are one of the important parts of treatment among the healthcare system in the early twentieth century due to the unavailability of the antibiotics and other synthetic drug 
molecules [1]. With increasing development of the antibiotic's era, popularity of herbal medicine among people was gradually decreased, due to fast therapeutic actions of synthetic drugs. But now-a-days, allopathic medicines have some limitations due to its adverse action [2]. However, herbal based test formulation has gained momentum in some cases as compared with the synthetic drugs. Besides, herbal based treatment approach, minerals, vitamins, and other vital constituents are also one of the treatment strategies in health care systems for powerful healing. Herbal system based pharmaceutical companies are continuing research on development of some unique formulations and are investing on research, development and popularizing such novel formulations. Herb mineral formulations are reported to be useful against overall health diseases such as high blood pressure, heart disease, asthma, other respiratory diseases, immunodeficiency diseases, aging and many more $[3,4]$. Thus, a novel herb mineral test formulation has been developed that would improve the overall functioning of multiple organs using standard cell line-based bioassay. However, till date no such scientific reports are available with respect to the herbal-based test formulation, which can improve the overall organ health. The novel test formulation was the combination of herbal products viz. panax ginseng extract and beta carotene, minerals viz. calcium chloride, magnesium gluconate, zinc chloride, sodium selenite, ferrous sulfate, and vitamins viz. vitamin $B_{12}$, vitamin $D_{3}$, ascorbic acid, and vitamin $\mathrm{B}_{6}$. This novel formulation was designed for improving overall organ function against various pathological conditions. Minerals and vitamins added in the test formulation are useful to support organ health and its functioning [5-8]. Panax ginseng overall improve wellness and thinking, memory, concentration, physical stamina, work efficiency, preventing musscle damage, Alzheimer's disease, athletic endurance, improve mental and cognitive health, and is a potent immunomodulator $[9,10]$. The above novel combination of constituents was tested against specific organ-based cell lines that were tested for biological activities. The specific activities included bone health study using MG-63 cells, lung health study using A549 cells, liver health study using HepG2 cells, heart health study using Human Cardiac fibroblasts, and neuronal health study using SH-SY5Y cells [11-20]. Before testing, the test formulation and the cell line specific media was treated with the complementary medicine i.e. Biofield Energy (The Trivedi Effect ${ }^{\circledR}$ - Consciousness Energy Healing) Treatment by a renowned Biofield Energy Healer.

Biofield Energy Treatment is one of the advanced Complementary and Alternative Treatment method, which has gained a strong scientific foundation using the concept of homodynamic regulation of living systems. Biofield Energy Healing Modalities as CAM approach is reported to be significantly useful to improve the overall physical, mental, and emotional human wellness [21-24] without any invasive procedures. Thus, Biofield Energy Treatment is one of the best unifying concepts between the traditional and contemporary explanatory energy models. The Trivedi Effect ${ }^{\circledR}$-Consciousness Energy Healing has been accepted worldwide with significant results in the field of metal science [25,26], agriculture science [27], microbiology [28,29], biotechnology [30,31], and improved compounds bioavailability $[32,33]$, dermatology [34,35], nutraceuticals [36], cancer research [37], bone health [38-40], human health and wellness. Due to the continued clinical and preclinical applications of Biofield Energy Healing Treatments, the test formulation was studied for impact of the Biofield Energy Healing Treated test formulation on the function of vital organs such as bones, heart, liver, lungs, and brain specific biomarkers in different standard cell-lines.

\section{Materials and Methods}

\section{Chemicals and reagents}

Calcium chloride, ferrous sulfate, vitamin $\mathrm{B}_{6}$, vitamin $\mathrm{B}_{12}$, vitamin $\mathrm{D}_{3}$, naringenin, Trimetazidine (TMZ), 3-(4,5-Dimethylthiazol2-yl)-2,5-Diphenyltetrazolium Bromide (MTT), and Ethylenediaminetetraacetic acid (EDTA) were procured from Sigma Chemical Co. (St. Louis, MO). Magnesium gluconate, zinc chloride, $\beta$-carotene, and calcitriol were procured from TCI chemicals, Japan. Panax ginseng extract was obtained from panacea Phytoextracts, India. Sodium selenite and ascorbic acid were procured from Alfa Aesar, India. Silymarin and curcumin were procured from Sanat Chemicals, India, while quercetin was purchased from Clear synth, India. Reverse Transcription Kit, RNeasy Mini Kit, and Syber Green PCR kits were procured from Qiagen, India. All the other chemicals used in this experiment were analytical grade procured from India.

\section{Biofield energy healing treatment}

The test formulation was the combination of eleven ingredients viz. calcium chloride, panax ginseng extract, vitamin $B_{12}, \beta$-carotene, vitamin $D_{3}$, zinc chloride, magnesium gluconate, sodium selenite, ferrous sulfate, ascorbic acid, and vitamin $B_{6}$. The test formulation/ media was divided into two parts, as the untreated group, where no Biofield Energy Treatment was provided, while another part defined as Biofield Energy Healing Based test formulation/ media. The untreated group was treated with a "sham" healer for comparison purposes, who did not have any knowledge about the Biofield Energy Healing Treatment. The rest constituents of the test formulation/media received Biofield Energy Treatment (The Trivedi Effect ${ }^{\circledR}$ ) remotely by Eileen Mary Meagher, under standard laboratory conditions for $\sim 3$ minutes through healer's unique Biofield Energy Transmission process and were referred as the Biofield Energy Treated formulation/media. The Biofield Energy Healer was located in the USA; however, the test formulation/ media were located in the research laboratory of Dabur Research Foundation, New Delhi, India. Biofield Energy Healer in this experiment did not visit the laboratory, nor had any contact with the test samples. Further, Biofield Energy Treated and untreated test items were kept in similar sealed conditions and used for the study as per the study plan.

\section{MTT test for cell viability assay}

All the experimental cells used in this study were counted for cell viability using hemocytometer in 96-well plates at the specific density as mentioned in the Table 1 . The cells were then incubated overnight under standard growth conditions to 
allow cell recovery and exponential growth. Following overnight incubation, cells were treated with different concentrations of test formulations (BT/UT). After respective treatments, the cells were incubated in a $\mathrm{CO}_{2}$ incubator at $37{ }^{\circ} \mathrm{C}, 5 \% \mathrm{CO}_{2}$, and $95 \%$ humidity. After incubation, the plates were taken out and $20 \mu \mathrm{L}$ of $5 \mathrm{mg} / \mathrm{mL}$ of MTT 3-(4,5-dimethylthiazol-2-yl)-2,5-diphenyl tetrazolium bromide solution was added to all the wells followed by additional incubation for 3 hours at $37^{\circ} \mathrm{C}$. The supernatant was aspirated and $150 \mu \mathrm{L}$ of DMSO was added to each well to dissolve formazan crystals. The absorbance of each well was read at $540 \mathrm{~nm}$ using Synergy HT microplate reader. The percentage cytotoxicity at each tested concentration was calculated using Equation 1:

$$
\text { \%Cytotoxicity=[(R-X)/R] *100............ }
$$

Where, $\mathrm{X}=$ Absorbance of treated cells; $\mathrm{R}=$ Absorbance of untreated cells

Table 1: Information related to six cell lines with their plating density and time-point.

\begin{tabular}{|c|c|c|c|}
\hline S. No. & Cell Line & Plating & Time Point \\
\hline 1 & MG-63 (Bone) & $3 \times 10^{4}$ cells/ well, 96-well plate & 5 days \\
\hline 2 & Ishikawa (Uterus) & $3 \times 10^{4}$ cells/well, 96-well plate & 5 days \\
\hline 3 & A549 (Lung) & $10 \times 10^{4}$ cells/ well, 96-well plate & 24 hours \\
\hline 4 & HepG2 (Liver) & $1 \times 10^{4}$ cells/ well, 96-well plate & 24 hours \\
\hline 5 & Human Cardiac fibroblasts (Heart) & $1 \times 10^{4}$ cells/ well, 96-well plate & 24 hours \\
\hline 6 & SH-SY5Y (Neuronal cell) & $10 \times 10^{4}$ cells/ well, 96-well plate & 24 hours \\
\hline
\end{tabular}

The concentrations exhibiting percentage cytotoxicity $<30 \%$ was considered as non-cytotoxic [41].

\section{Cytoprotective effect of the test formulation}

Cytoprotective effect of the test formulation in various cells such as human cardiac fibroblasts-HCF; human hepatoma cells-HepG2; and adenocarcinoma human alveolar basal epithelial cells-A549 were counted and plated in suitable medium followed by overnight incubation. Further, the cells were then treated with the test items/ positive control at the non-cytotoxic concentrations for 24 hours. After 24 hours, the oxidative stress using $10 \mathrm{mM} t$-BHP for 3.5 hours was given to the cells. The cells treated with $10 \mathrm{mM}$ of $t$-BHP alone served as negative control. After 3.5 hours of incubation with $t$-BHP the above plates were taken out and cell viability was determined by MTT assay. The percentage protection corresponding to each treatment was calculated using equation 2 :

$\%$ Protection $=\left[\left(\right.\right.$ Absorbance $_{\text {sample }}-$ Absorbance $\left.\left._{\mathrm{t}-\mathrm{BHP}} \mathrm{P}\right)\right] * 100 /$ $\left[\right.$ Absorbance $_{\text {untreated }}-$ Absorbance $\left._{\mathrm{t}_{\mathrm{B} B \mathrm{BP}}}\right]$ s............... (2)

\section{Estimation of alkaline phosphatase (ALP) activity}

For the estimation of ALP, the cells (human bone osteosarcoma cells-MG-63 and human endometrial adenocarcinoma cellsIshikawa) were counted using a hemocytometer and plated in 24-well plates at the density corresponding to $1 \mathrm{X} 10^{4}$ cells/well in phenol-free DMEM supplemented with $10 \%$ CD-FBS. Following the respective treatments, the cells in the above plate were incubated for 48 hours in $\mathrm{CO}_{2}$ incubator at $37{ }^{\circ} \mathrm{C}, 5 \% \mathrm{CO}_{2}$, and $95 \%$ humidity. After 48 hours of incubation, the plates were taken out and processed for the measurement of ALP enzyme activity. The cells were washed with 1XPBS and lysed by freeze-thaw method i.e., incubation at $-80{ }^{\circ} \mathrm{C}$ for 20 minutes followed by incubation at 37 ${ }^{\circ} \mathrm{C}$ for 10 minutes. To the lysed cells, $50 \mu \mathrm{L}$ of substrate solution i.e. $5 \mathrm{mM}$ of $p$-nitrophenyl phosphate ( $p \mathrm{NPP}$ ) in $1 \mathrm{M}$ diethanolamine and $0.24 \mathrm{mM}$ magnesium chloride $\left(\mathrm{MgCl}_{2}\right)$ solution $(\mathrm{pH}=10.4)$ was added to all the wells followed by incubation for 1 hour at $37{ }^{\circ} \mathrm{C}$. The absorbance of the above solution was read at $405 \mathrm{~nm}$ using Synergy HT microplate reader (Biotek, USA). The absorbance values obtained were normalized with substrate blank ( $p$ NPP solution alone) absorbance values. The percentage increase in ALP enzyme activity with respect to the untreated cells (baseline group) was calculated using Equation 3:

$\%$ Increase in ALP $=\{(\mathrm{X}-\mathrm{R}) / \mathrm{R}\} * 100$

Where, $\quad \mathrm{X}=$ Absorbance of cells corresponding to positive control and test groups

$\mathrm{R}=$ Absorbance of cells corresponding to baseline group (untreated cells)

\section{Estimation of lactate dehydrogenase (LDH) in human cardiac fibroblasts (HCF) cells}

HCF cells were counted and plated at the density of $0.25 \times 10^{6}$ cells/ well in 24-well plates in cardiac fibroblast specific medium followed by overnight incubation. The cells were then treated with the test formulation combinations/positive control at the noncytotoxic concentrations for 24 hours. After 24 hours, oxidative stress was given to the cells using $10 \mathrm{mM} t$-BHP for 3.5 hours. The untreated cells were served as control group, which did not receive any treatment and were maintained in cell growth medium only. Cells treated with $10 \mathrm{mM}$ of $t$-BHP alone served as the negative control. After 3.5 hours of incubation with $t$-BHP, the above plates were taken out and LDH activity was determined using LDH activity kit as per manufacturer's instructions. The percent increase in LDH activity was calculated using Equation 4.

$\%$ Increase $=\left[\left(\mathrm{LDH}\right.\right.$ activity ${ }_{\text {sample }}-\mathrm{LDH}$ activity $\left.\left._{\mathrm{t}-\mathrm{BHP}}\right)\right] * 100 /[\mathrm{LDH}$ activity $_{\text {untreated }}-\mathrm{LDH}$ activity $\left.\mathrm{t}_{\mathrm{t} B \mathrm{~B}}\right] \ldots \ldots \ldots . . . . . . .(4)$

\section{Estimation of ALT in liver cells (HepG2)}

The human hepatoma cells (HepG2) were counted and plated at the density of $5 \times 10^{4}$ cells/well in 48-well plates in DMEM media followed by overnight incubation. The cells were then treated with the test formulation/positive control at the non-cytotoxic 
concentrations for 24 hours. After 24 hours, oxidative stress was given to the cells using $400 \mu \mathrm{M} t$-BHP for 3.5 hours. The untreated cells served as control that did not receive any treatment and were maintained in cell growth medium only. Cells treated with $400 \mu \mathrm{M}$ of $t$-BHP alone served as negative control. After 3.5 hours of incubation with $t$-BHP, the above plates were taken out and ALT activity was determined using ALT activity kit as per manufacturer's instructions. The percent increase in ALT activity was calculated using Equation 5.

$\%$ Increase $=\left[\left(\text { ALT } \text { activity }_{\text {sample }}-\text { ALT } \text { activity }_{\text {t-BHP }}\right)\right]^{* 100 /[\text { ALT }}$ activity $_{\text {untreated }}-$ ALT activity t_BHP $\left._{-}\right] \ldots . . . . . . . . . .(5)$

\section{Estimation of superoxide dismutase (SOD) in lung (A549) cells}

The adenocarcinoma human alveolar basal epithelial cells (A549) were counted and plated at the density of 1 X10 $0^{4}$ cells/well in 24-well plates in DMEM followed by overnight incubation. The cells were then treated with the test formulation/positive control at the non-cytotoxic concentrations along with $100 \mu \mathrm{M} t$-BHP to induce oxidative stress. The untreated cells served as control that did not receive any treatment and were maintained in cell growth medium only. Cells treated with $100 \mu \mathrm{M}$ of $t$-BHP alone served as negative control. After 24 hours of incubation with $t$-BHP the above plates were taken out and SOD activity was determined using SOD activity kit as per manufacturer's instructions. The percent increase in SOD activity was calculated using equation 6:

$\%$ Increase in SOD activity $=((\mathrm{X}-\mathrm{R}) / \mathrm{R}) * 100$. (6)

Where, $\mathrm{X}=$ SOD activity corresponding to test item or positive control

$\mathrm{R}=\mathrm{SOD}$ activity corresponding to Control group.

\section{Estimation of serotonin in neuronal cells (SH-SY5Y)}

The human neuroblastoma (SH-SY5Y) cells were counted and plated at the density of $10 \times 10^{4}$ cells/well in 96-well plates followed by overnight incubation. The cells were then treated with the test formulation/positive control at the non-cytotoxic concentrations. The untreated cells served as control that did not receive any treatment and were maintained in cell growth medium only. The treated cells were incubated for 24 hours. Serotonin release was determined by ELISA as per manufacturer's protocol. The percent increase in serotonin levels was calculated using equation 7 :

$$
[(\mathrm{X}-\mathrm{R}) / \mathrm{R}] * 100 \text {. }
$$

Where, $\mathrm{X}=$ Serotonin levels corresponding to test item or positive control,

$\mathrm{R}=$ Serotonin levels corresponding to control group.

\section{Effect of test formulation on Vitamin D Receptor (VDR) in bone (MG-63) cells}

The effect of test formulation on vitamin $\mathrm{D}$ receptor (VDR) activity in bone (MG-63) cells were counted using the hemocytometer at density $2 \times 10^{5}$ cells/well in 6-well plates followed by overnight incubation. The cells were then sera starved for 24 hours and treated with the test formulation/positive control at the non-cytotoxic concentrations, while control group did not receive any treatment, which were maintained in cell growth medium only. The treated cells were incubated for 24 hours and VDR expression was determined by qPCR using VDR specific primers. Cells were harvested by scrapping and washed with PBS. Cell pellets obtained were analyzed for VDR gene expression using human VDR specific primers: Forward: 5'-GCTGACCTGGTCAGTTACAGCA-3', Reverse: 5'-CACGTCACTGACGCGGTACTT-3'. VDR gene expression was normalized using Housekeeping (HK) reference. Relative Quantification (RQ) of VDR gene in Biofield Energy Treated cells was calculated with respect to the untreated cells using equation 8 :

$$
\mathrm{RQ}=2-\mathrm{N} \text {. }
$$

Where, $\mathrm{N}$ is the relative Threshold Cycle (CT) value of treated sample with respect to the untreated sample.

\section{Statistical Analysis}

All the values were represented as mean \pm SD (Standard Deviation) of three independent experiments. The statistical analysis was performed using Sigma Plot statistical software (v11.0). For two group comparison, student's $t$-test was used. For multiple group comparison, one-way analysis of variance (ANOVA) was used followed by post-hoc analysis by Dunnett's test. Statistically significant values were set at the level of $p \leq 0.05$.

\section{Results and Discussion}

\section{MTT assay for cell viability}

MTT assay was used initially for analyzing cell viability at various test concentrations. The initial results of MTT assay revealed that each cell line was found safe with respect to the tested concentrations of test formulation and were represented as percentage of cell viability. The criteria for selection of noncytotoxic concentrations were less than $30 \%$ cytotoxicity or greater than $70 \%$ cell viability using MTT assay. The experimental data suggested that the overall percent cell viability in different cell-lines viz. MG-63, Ishikawa, A549, HepG2, HCF, and SH-SY5Y. Based on the percent cell viability data, it was observed that the test formulation and positive controls were found safe and non-toxic at the tested concentrations. These test concentrations of the formulation were used cell-based assays.

\section{Evaluation of cytoprotective effect of the test formulation}

Cytoprotective action was tested on three cell lines. The experimental data represented in terms of percentage cellular protection against $t$-BHP induced cell damage and the results are shown in Figure 1. Trimetazidine (TMZ) was used as a positive control group in Human Cardiac Fibroblasts cells (HCF) for cytoprotective effect which showed significant restoration of cell viability by $48 \%, 57.2 \%$, and $87.2 \%$ at 5,10 , and $25 \mu \mathrm{M}$, respectively as compared to the t-BHP induced group. Besides, the restoration of cell viability among the tested groups by the test formulation was reported as $19.4 \%, 21.3 \%$, and $56.8 \%$ at $10,25.5$, and $63.75 \mu \mathrm{g} / \mathrm{mL}$ respectively, in the UT-Med+BT-TI as compared with the untreated test group. Similarly, restoration of cell viability was increased in 
BT-Med+UT-TI group was $25.5 \%$ and $57.5 \%$ at 25.5 and $63.75 \mu \mathrm{g} /$ $\mathrm{mL}$ respectively, while increased cellular restoration was reported by $124.8 \%, 30 \%, 15.7 \%$, and $63.2 \%$ at $1,10,25.5$, and $63.75 \mu \mathrm{g} /$ $\mathrm{mL}$ respectively in the BT-Med+BT-TI group as compared with the untreated test group. Similarly, silymarin was used as positive control in HepG2 cells, which resulted in significant cellular restoration by $40 \%, 65.9 \%$, and $86.6 \%$ at 5,10 and $25 \mu \mathrm{g} / \mathrm{mL}$, respectively as compared to the $t$-BHP induced group. Besides, test formulation groups such as in the UT-Med+BT-TI group showed increased cellular restoration by $40.8 \%, 4.9 \%$, and $83.2 \%$ at $1,25.5$, and $63.75 \mu \mathrm{g} / \mathrm{mL}$ respectively, as compared to the untreated test group. Besides, the test formulation showed maximum restoration of cell viability by $83.4 \%, 26.7 \%$, and $93.8 \%$ at $10,25.5$, and $63.75 \mu \mathrm{g} / \mathrm{mL}$ respectively, in the BT-Med+UT-TI group. Similarly, $20.6 \%$ improved cellular restoration was reported at $10 \mu \mathrm{g} / \mathrm{mL}$ in the BT-Med+BT-TI group as compared to the UT-Med+UT-TI group. In addition, quercetin was used as positive control in adenocarcinoma human alveolar basal epithelial cells (A549) resulted, restoration of cell viability by $56.8 \%$ and $66.4 \%$ at 10 and $25 \mu \mathrm{M}$, respectively compared to the t-BHP induced group. Besides, the test formulation showed maximum restoration of cell viability by $3.7 \%, 5 \%, 11.3 \%$, and $9.6 \%$ at $1,10,25.5$, and $63.75 \mu \mathrm{g} / \mathrm{mL}$ respectively, in the UTMed+BT-TI group. Similarly, 57.3\%, 12.2\%, 15.5\%, and $82.7 \%$ improved cellular restoration was reported at 1, 10, 25.5, and $63.75 \mu \mathrm{g} / \mathrm{mL}$ respectively, at BT-Med+UT-TI groups as compared to the UT-Med+UT-TI group. However, 33.2\%, 92\%, 113.9\%, and $82.1 \%$ improved cellular restoration was reported at $1,10,25.5$, and $63.75 \mu \mathrm{g} / \mathrm{mL}$ respectively, at BT-Med+BT-TI groups as compared to the UT-Med+UT-TI group. Cytoprotecting of cells against test formulation can be determined using tert-butyl hydroperoxide ( $t$-BHP) method [41,42]. Cytoprotecting defines the rate of cellular injuries and oxidative stress that can induce cell death [43-47]. The present experimental data showed significant improved cellular protection after Biofield Energy Healing Treatment (The Trivedi Effect $(\circledR)$ against vital organs and their functioning viz. heart, liver, and lungs. Overall, it can be useful to manage the oxidative stress induced by various factors against pathological etiologies of cardiovascular, liver, and various lung diseases.

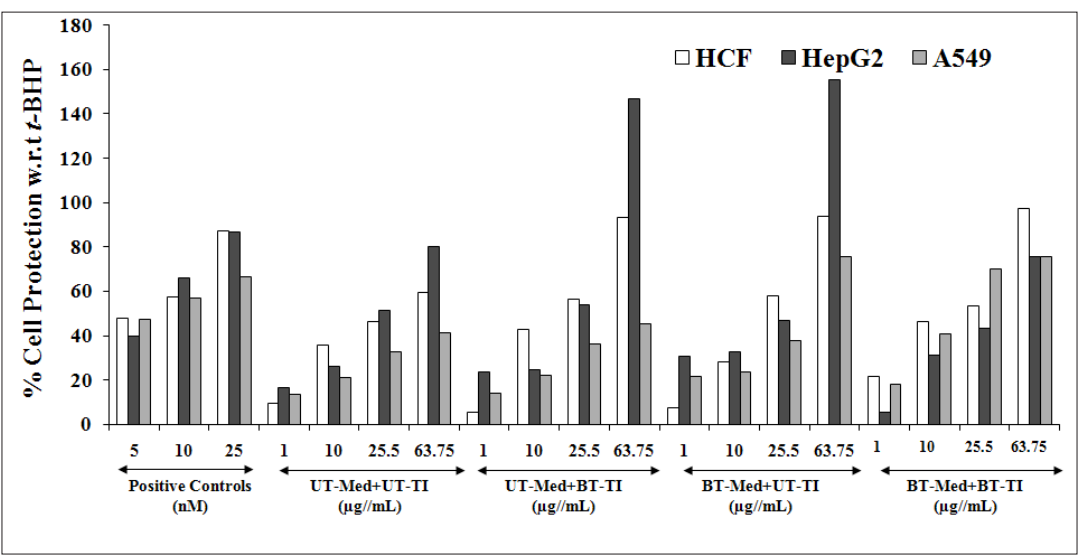

Figure 1. Cytoprotective action of the test formulation in human cardiac fibroblasts cells.

(HCF), Human Hepatoma Cells (HepG2), and adenocarcinoma human alveolar basal epithelial cells (A549) against tert-butyl hydroperoxide (t-BHP) induced damage. Trimetazidine $(\mu \mathrm{M})$, silymarin $(\mu \mathrm{g} / \mathrm{mL})$, and quercetin $(\mu \mathrm{M})$ were used as positive control in HCF, HepG2, and A549 cells, respectively. UT: Untreated; Med: Medium; BT: Biofield Treated; TI: Test Item.

\section{Estimation of Alkaline Phosphatase (ALP) activity}

ALP activity was evaluated using cell lines viz. MG-63 and Ishikawa cells. Naringenin was used as positive control for Ishikawa cells, and the data showed significant improved level of ALP by $18.3 \%, 35.8 \%$, and $109.4 \%$ at $0.1,1$, and $10 \mu \mathrm{M}$ respectively (Figure 2). However, the experimental test groups showed increased ALP activity by $59.8 \%, 24.5 \%$, and $8.4 \%$ at $0.1,10$, and $50 \mu \mathrm{g} / \mathrm{mL}$ respectively, in the UT-Med+BT-TI group as compared to the UT-Med+UT-TI group in MG-63 cells. In addition, ALP activity was increased by $269.7 \%, 60.8 \%$, and $59.7 \%$ at $0.1,10$, and $50 \mu \mathrm{g} /$ $\mathrm{mL}$ respectively, in the BT-Med+UT-TI group as compared to the UT-Med+UT-TI group. Similarly, ALP activity was increased by $105.7 \%, 25.8 \%$, and $47.6 \%$ at $0.1,10$, and $50 \mu \mathrm{g} / \mathrm{mL}$ respectively, in the BT-Med+BT-TI group as compared to the UT-Med+UT-TI group. Similarly, calcitriol (nM) was used as positive control in the MG-63 cells, and the results suggested significant increased ALP level by $12 \%, 23 \%$, and $53.5 \%$ at $0.1,1$, and $10 \mathrm{nM}$ respectively as presented in Figure 2. In the experimental tested groups, the ALP percent was significantly increased by $87.2 \%$ and $86.4 \%$ at 10 and $50 \mu \mathrm{g} / \mathrm{mL}$, respectively in the UT-Med+BT-TI group as compared to the UT-Med + UT-TI group. Similarly, ALP percent was significantly increased by $94.8 \%$ and $83.4 \%$ at 10 and $50 \mu \mathrm{g} / \mathrm{mL}$, respectively in the BT-Med+UT-TI group as compared to the UT-Med+UT-TI group. However, ALP percent was significantly increased by $94.2 \%$ and $89.4 \%$ at 10 and $50 \mu \mathrm{g} / \mathrm{mL}$, respectively in the BT-Med+BT-TI group as compared to the UT-Med+UT-TI group. ALP is one of the best bone health biomarkers, however significant increased level denoted recovery in bone related disorders [48,49]. Overall, the experimental data suggested significant improved ALP level after Biofield Energy Healing Treatment that has important application in low bone density, osteoporosis, osteogenesis imperfect and Paget's disease of bone that makes the bones brittle. 


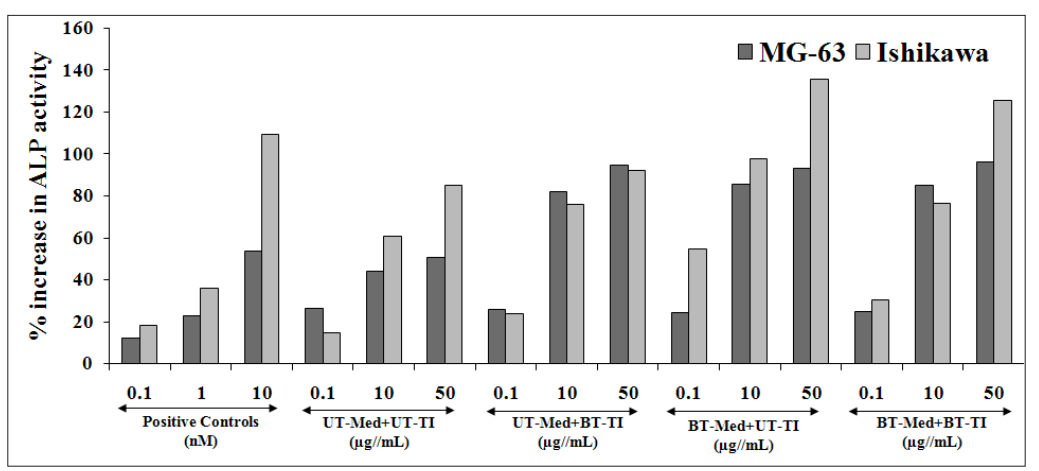

Figure 2: Alkaline Phosphatase (ALP) activity in human bone osteosarcoma cells (MG-63) and human endometrial adenocarcinoma cells (Ishikawa) after treatment of the test formulation. Calcitriol and naringenin were used as positive control in MG-63 and Ishikawa cells, respectively.

UT: Untreated; Med: Medium; BT: Biofield Treated; TI: Test item

\section{Identification of Lactate Dehydrogenase (LDH) activity in Human Cardiac Fibroblasts (HCF)}

LDH activity was represented in terms of decreased LDH activity, which represents increased cellular protection of $\mathrm{HCF}$ cells (Figure 3). The positive control, Trimetazidine (TMZ) showed $63.1 \%, 92.3 \%$, and $115.2 \%$ increased cellular protection of HCF cells (decreased of LDH activity) at 10, 50, and $100 \mu \mathrm{M}$ concentration as compared to the $t$-BHP group. The test formulation showed maximum percent protection of HCF cells (decreased of LDH activity), which was significantly increased by $48.8 \%, 31.5 \%$, and $44 \%$ at 1,10 , and $25.5 \mu \mathrm{g} / \mathrm{mL}$ concentrations respectively, in the UT-Med+BT-TI group, while $62.9 \%$ and $47 \%$ improved cellular protection (decreased of LDH activity) at 10 and $25.5 \mu \mathrm{g} / \mathrm{mL}$ respectively in the BT-Med+UT-TI group, and 103\% and $99.9 \%$ improved cellular protection (decreased of LDH activity) 1 and $10 \mu \mathrm{g} / \mathrm{mL}$ respectively, in BT-Med+BT-TI group as compared to the UT-Med+UT-TI group. LDH has important role in the tissue injury, hemolysis, necrosis, hypoxia, or malignancies, however it plays a central role in maintenance of extracellular matrix for normal heart functioning and clinical importance in useful in living cells of blood cells, skeletal muscle, and heart muscle. Besides, HCF cells are used for the estimation of LDH activity, which represents heart health [50-52]. The present data concluded a significant reduction of LDH level after Biofield Energy Treatment and protection of the HCF cells, which would be useful in different pathological conditions.

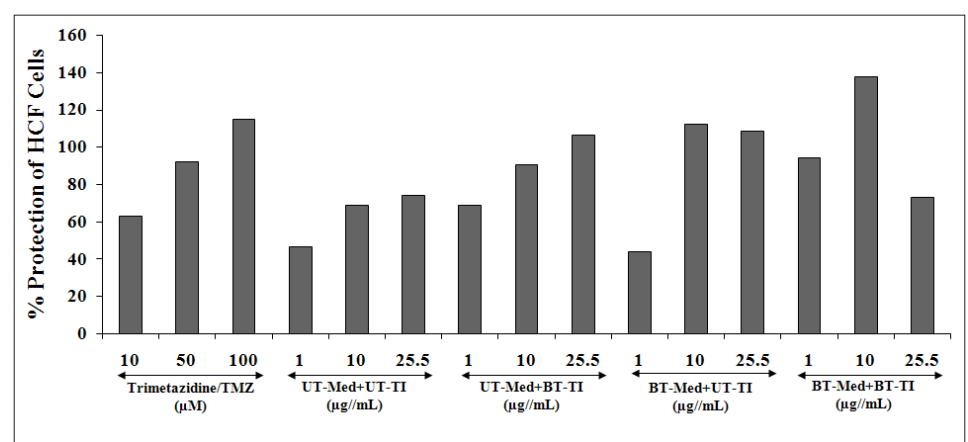

Figure 3: The effect of the test formulation on the percent protection of HCF cells in terms of decreased Lactate Dehydrogenase (LDH) activity against tert-butyl hydroperoxide ( $t$-BHP) induced damage.

TMZ: Trimetazidine; UT: Untreated; Med: Medium; BT: Biofield Treated; TI: Test Item.

\section{Estimation of alanine amino transferase (ALT) activity in HepG2 cells}

ALT activity was tested in HepG2 cells and the results are presented in terms of decreased ALT activity (Figure 4), which showed increased cellular protection of HepG2 cells. The positive control, silymarin was selected in ALT activity and the data suggested increased percentage cellular protection (decreased ALT activity) by $56 \%, 85 \%$, and $118.9 \%$ at 5,10 , and $25 \mu \mathrm{M}$ concentrations, respectively. Similarly, the test formulation groups showed improved cellular protection of HepG2 cells (decreased of
ALT activity) by $25.4 \%, 30.5 \%$, and $22.8 \%$ at $10,25.5$, and $63.75 \mu \mathrm{g} /$ $\mathrm{mL}$ respectively, in the UT-Med+BT-TI group, while increased cellular protection of HepG2 cells (decreased of ALT activity) by $29.1 \%$ and $74.9 \%$ at 10 and $63.75 \mu \mathrm{g} / \mathrm{mL}$ respectively, in the BTMed+UT-TI group, and increased cellular protection of HepG2 cells (decreased of ALT activity) by $15.9 \%, 25.4 \%$, and $84.9 \%$ at 10 , 25.5 , and $63.75 \mu \mathrm{g} / \mathrm{mL}$ respectively, in the BT-Med+BT-TI group as compared to the UT-Med+UT-TI group (Figure 4). Liver has many enzymes among which ALT are one of the important in regulating various physiological processes. It has important function in cellular energy production and vital role in hepatocellular injury and death 
[53]. Alteration in ALT enzyme represents liver or cellular damage [54]. The data showed significant increased cellular protection of HepG2 cells after Biofield Energy Treatment (The Trivedi Effect ${ }^{\circledR}$ ), which significantly protects the liver hepatocytes that can be useful in liver cancer, liver cirrhosis, hepatomegaly, liver failure, and hepatitis.

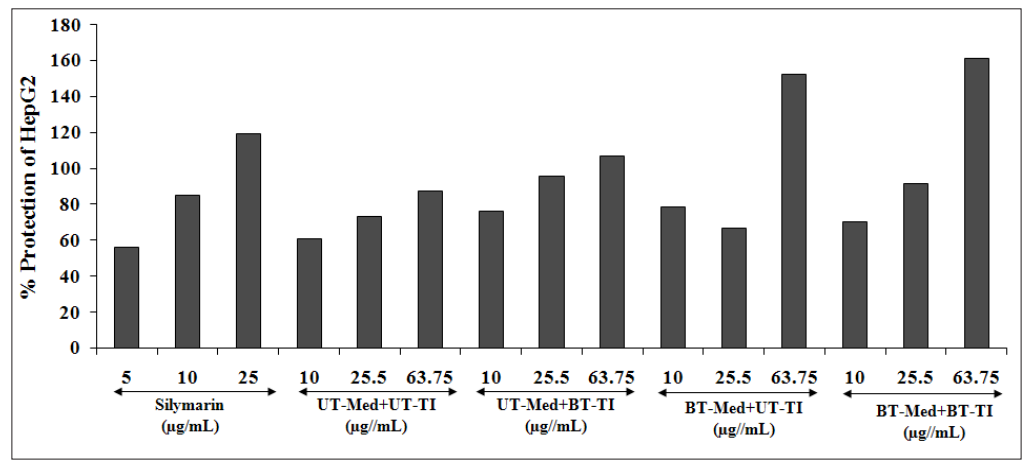

Figure 4: The effect of the test formulation on the percent protection of human liver cancer (HepG2) cells in terms of decreased Alanine Amino Transaminase (ALT) activity under the stimulation of tert-butyl hydroperoxide $(t-\mathrm{BHP})$.

UT: Untreated; Med: Medium; BT: Biofield Treated; TI: Test Item.

Estimation of Superoxide Dismutase (SOD) activity in adenocarcinoma human alveolar basal epithelial cells (A549)

A549 cells were used for the estimation of SOD activity, and the results were represented in terms of increased cellular protection and the data was presented in Figure 5. The positive control, quercetin showed improved percentage increase in the SOD activity with respect to the $t$-BHP by $68.4 \%, 83.9 \%$, and $104.2 \%$ at 10,25 , and $50 \mu \mathrm{M}$ concentration respectively. However, the percent protection of A549 (lungs) cells (increased of SOD activity) was significantly increased by $21.7 \%$ and $19.1 \%$ at 25.5 and $63.75 \mu \mathrm{g} /$ $\mathrm{mL}$, respectively in the UT-Med+BT-TI group, while increased SOD activity by $83.2 \%, 33.1 \%$, and $59.2 \%$ at $0.1,25.5$, and $63.75 \mu \mathrm{g} /$
$\mathrm{mL}$ respectively, in the BT-Med+UT-TI group, and increased SOD activity by $40 \%$ and $10 \%$ at 25.5 and $63.75 \mu \mathrm{g} / \mathrm{mL}$ respectively, in the BT-Med+BT-TI group as compared to the UT-Med+UT-TI group (Figure 5). The data suggested that Biofield Energy Healing Treatment significantly improved the cellular protection of A549 cells and increased SOD enzyme in all the test groups. SOD act as the body defense system that is responsible for high antioxidant activity against cellular damage due to free radicals, Reactive Oxygen Species (ROS), and many other factors causing cell death [55]. Biofield Energy Healing Treatment has significantly improved the SOD activity that can be used in various respiratory diseases such as pneumonia, asthma, pulmonary fibrosis, and lung cancer.

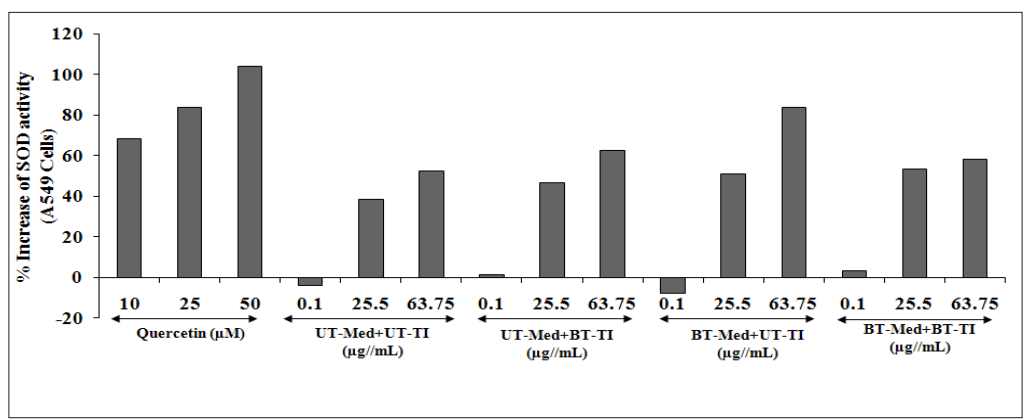

Figure 5: The effect of the test formulation on the percent protection of lungs cells (A549) in terms of increased SOD activity under the stimulation of tert-butyl hydroperoxide ( $t$-BHP).

UT: Untreated; Med: Medium; BT: Biofield Treated; TI: Test Item

Data are expressed as mean $\pm \mathrm{SD}$ of three independent experiments.

\section{Estimation of serotonin level in human neuroblastoma (SH-SY5Y) cells}

The change in serotonin level was estimated in all the experimental groups using standard cell-based assay after 24 hours of treatment using ELISA method. Serotonin activity was in different test groups are presented in Figure 6. The positive control, curcumin showed $96.1 \%, 137.2 \%$, and $169.6 \%$ increase the level of serotonin at $0.1,1$, and $5 \mu \mathrm{M}$ respectively, compared to the Vehicle Control (VC) group. The data showed significant increased serotonin level by $22.3 \%, 22 \%$, and $50.8 \%$ at 10,25 , and $63.75 \mu \mathrm{g} /$ $\mathrm{mL}$ respectively, in the UT-Med+BT-TI, while significant increased 
serotonin by $35.9 \%$ and $4.6 \%$ at 10 and $63.75 \mu \mathrm{g} / \mathrm{mL}$ respectively, in the BT-Med+UT-TI, and 49.9\%, 2.2\%, and $14.1 \%$ improved serotonin level at 10,25 , and $63.75 \mu \mathrm{g} / \mathrm{mL}$ respectively, in the BTMed+BT-TI group as compared to the UT-Med+UT-TI group (Figure 6). Biofield Energy Healing Treatment significantly improved the serotonin (a neurotransmitter) level in all the groups, which can be used against various neurodegenerative diseases and improved brain functioning. Serotonin improves the mood and social behavior, appetite and digestion, sleep, memory, and sexual desire and related functions. It has important mechanism in the brain, bowels, and blood platelets. Serotonin inhibition leads to neuropsychiatric disorders such as emesis, Irritable Bowel Syndrome (IBS), and pulmonary and systemic hypertension, Alzheimer's disease, cognitive health, loss of ability of thinking, migraine, depression, memory loss, etc. [56-59].

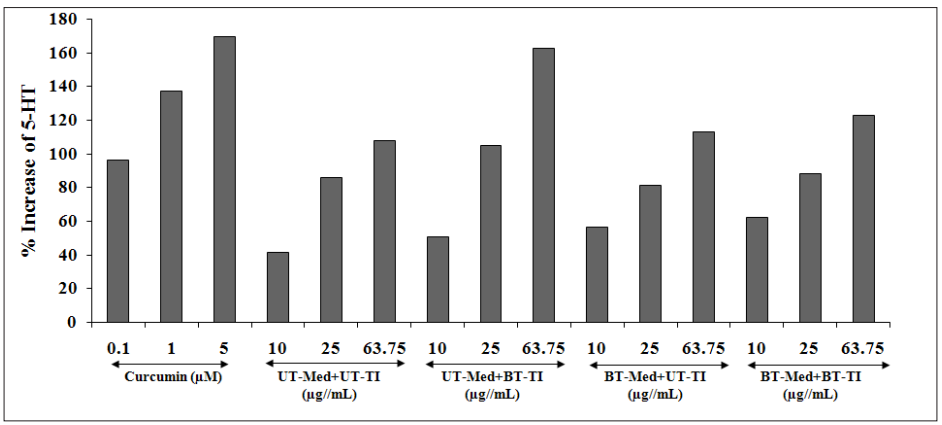

Figure 6: The effect of the test formulation on percent increase in 5-Hydroxy Tryptamine (5-HT) or serotonin in human neuroblastoma cells (SH-SY5Y).

UT: Untreated; Med: Medium; BT: Biofield Treated; TI: Test Item

Evaluation of Vitamin D Receptors (VDRs) activity in human bone osteosarcoma cells (MG-63)

VDR activity was estimated using MG-63 cells and its expression was studies using the phenomenon of ligand binding through vitamin $\mathrm{D}$ active molecule that can be find out using quantitativepolymerase chain reaction (qPCR) amplification. Using real time PCR, different VDR-relative threshold cycle (VDR-CT) values were obtained after complete amplification cycles using specific primer probes. Relative Quantification (RQ) was calculated from the VDRCT and housekeeping (HK)-CT values in MG-63 cells. The VDR-CT values of different experimental test groups are represented in Figure 7. Calcitriol was used as a positive control and the RQ of VDR was found to be increased in concentration-dependent manner by $59.1 \%, 93.2 \%$, and $131.3 \%$ at 1,10 , and $100 \mathrm{nM}$, respectively. The experimental test groups showed increased RQ of VDR expression by $91.2 \%, 62.4 \%$, and $135.2 \%$ in the UT-Med+BT-TI group at 1,10 , and $50 \mu \mathrm{g} / \mathrm{mL}$ respectively, while $184.3 \%, 242.4 \%$, and $291.4 \%$ increased RQ of VDR at 1,10 , and $50 \mu \mathrm{g} / \mathrm{mL}$ respectively, in the BTMed+UT-TI group, and increased RQ of VDR by $196.2 \%, 289.8 \%$, and $248.3 \%$ at 1,10 , and $50 \mu \mathrm{g} / \mathrm{mL}$ respectively, in the BT-Med+BT-TI group as compared to the UT-Med+UT-TI group. The overall results showed significant increased RQ-VRD expression in MG-63 cells and improved vitamin activity after treatment in various groups. Calcitriol binds with the VDRs and extensively regulates the calcium homeostasis, immunity, overall cellular growth, bone growth, and differentiation [60-62]. The results were well collaborated and can be concluded that after treatment the activity of VDR expression was significantly improved.

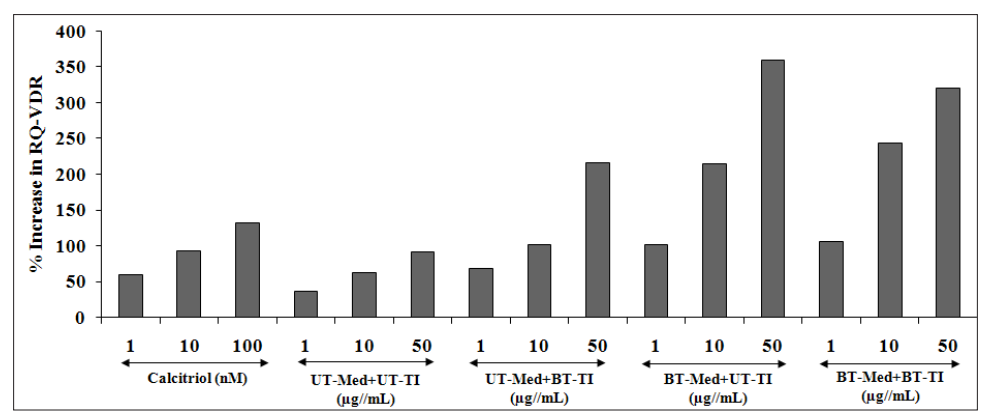

Figure 7: Effect of the test formulation on percent increase in Relative Quantification (RQ) of Vitamin D Receptors (VDRs) gene in human bone osteosarcoma cells (MG-63).

UT: Untreated; Med: Medium; BT: Biofield Treated; TI: Test Item

\section{Conclusion}

The test formulation was found safe and non-toxic using standard MTT cell viability assay against tested cell lines. MTT assay showed that the test formulation was found safe all the tested cell lines. Cytoprotective activity against $t$-BHP induced cell damage was tested using Human Cardiac Fibroblasts Cells (HCF), which showed restoration of cell viability by $56.8 \%$ (at $63.75 \mu \mathrm{g} / \mathrm{mL}$ ), $57.5 \%$ (at 
$63.75 \mu \mathrm{g} / \mathrm{mL}$ ), and $124.8 \%$ (at $1 \mu \mathrm{g} / \mathrm{mL}$ ) in the UT-Med+BT-TI, BT-Med+UT-TI, BT-Med+BT-TI groups respectively, as compared to the untreated test group, while in HepG2 cells the maximum restoration of cell viability by $83.2 \%$ (at $63.75 \mu \mathrm{g} / \mathrm{mL}$ ), $93.8 \%$ (at $63.75 \mu \mathrm{g} / \mathrm{mL}$ ), and $20.6 \%$ (at $10 \mu \mathrm{g} / \mathrm{mL}$ ) in the UT-Med+BT-TI, BTMed+UT-TI, BT-Med+BT-TI groups respectively, as compared to the untreated test group. Similarly, the test formulation in A549 cells showed maximum restoration of cell viability by $11.3 \%$ (at $25.5 \mu \mathrm{g} /$ $\mathrm{mL}$ ), $82.7 \%$ (at $63.75 \mu \mathrm{g} / \mathrm{mL}$ ), and $113.9 \%$ (at $25.5 \mu \mathrm{g} / \mathrm{mL}$ ) in the UTMed+BT-TI, BT-Med+UT-TI, and BT-Med+BT-TI groups respectively, as compared to the untreated test group. ALP activity in Ishikawa cells showed significantly increased ALP activity by $59.8 \%$ (at $0.1 \mu \mathrm{g} / \mathrm{mL}$ ), $269.7 \%$ (at $0.1 \mu \mathrm{g} / \mathrm{mL}$ ), and $105.7 \%$ (at $0.1 \mu \mathrm{g} / \mathrm{mL}$ ) in the UT-Med+BT-TI, BT-Med+UT-TI group, and BT-Med+BT-TI groups respectively, as compared to the untreated test group. Similarly, ALP activity in MG-63 cells with maximum cellular protection at $10 \mu \mathrm{g} / \mathrm{mL}$ by $87.2 \%, 94.8 \%$, and $94.2 \%$ in the UT-Med+BT-TI, BTMed+UT-TI, BT-Med+BT-TI groups respectively, as compared to the untreated test group. LDH data was presented in terms of increased percentage cellular protection data, which suggested significant decreased activity, which showed maximum cellular protection by $48.8 \%$ (at $1 \mu \mathrm{g} / \mathrm{mL}$ ), $62.9 \%$ (at $10 \mu \mathrm{g} / \mathrm{mL}$ ), and $103 \%$ (at $1 \mu \mathrm{g} / \mathrm{mL}$ ) in the UT-Med + BT-TI, BT-Med+UT-TI group, and BT-Med+BT-TI groups respectively, as compared to the untreated test group. ALT activity was studied and data showed maximum improved cellular protection of HepG2 cells (decreased of ALT activity) by $30.5 \%$ (at $25.5 \mu \mathrm{g} / \mathrm{mL}$ ), $74.9 \%$ (at $63.75 \mu \mathrm{g} / \mathrm{mL}$ ), and $84.9 \%$ (at $63.75 \mu \mathrm{g} /$ $\mathrm{mL}$ ) in the UT-Med+BT-TI, BT-Med+UT-TI group, and BT-Med+BTTI groups respectively, as compared with the untreated test group. SOD activity was significantly increased by $21.7 \%$ (at $25.5 \mu \mathrm{g} / \mathrm{mL}$ ), $83.2 \%$ (at $0.1 \mu \mathrm{g} / \mathrm{mL}$ ), and $40 \%$ (at $25.5 \mu \mathrm{g} / \mathrm{mL}$ ) in the UT-Med+BTTI, BT-Med+UT-TI group, and BT-Med+BT-TI groups respectively, as compared with the untreated test group. Serotonin level was significantly increased in SH-SY5Y cells by $50.8 \%$ (at $63.75 \mu \mathrm{g} / \mathrm{mL}$ ), $35.9 \%$ (at $10 \mu \mathrm{g} / \mathrm{mL}$ ), and $49.9 \%$ (at $10 \mu \mathrm{g} / \mathrm{mL}$ ) in UT-Med+BT-TI, BT-Med+UT-TI, and BT-Med+BT-TI groups respectively, as compared with the untreated test group. However, VDR expression was tested in MG-63 cells, which showed increased RQ of VDR by $91.2 \%$, $62.4 \%$, and $135.2 \%$ in the UT-Med+BT-TI group at , 10 , and $50 \mu \mathrm{g} /$ $\mathrm{mL}$ respectively, while $184.3 \%, 242.4 \%$, and $291.4 \%$ increased RQ of VDR at 1,10 , and $50 \mu \mathrm{g} / \mathrm{mL} \mu \mathrm{g} / \mathrm{mL}$ respectively, in the BTMed+UT-TI group, and increased RQ of VDR by $196.2 \%, 289.8 \%$, and $248.3 \%$ at 1,10 , and $50 \mu \mathrm{g} / \mathrm{mL}$ respectively, in the BT-Med+BTTI group as compared to the untreated test control group. Biofield Energy Treatment (The Trivedi Effect ${ }^{\circledR}$ ) significantly improved the cellular protection and overall organ health, which can be used in various cardiac disorders such as stroke, thromboembolic disease, congestive heart failure, congenital heart disease, peripheral artery disease, rheumatic heart disease, valvular heart disease, and venous thrombosis, etc. Besides, it would also protect against many hepatic disorders (cirrhosis, liver cancer, hemochromatosis, Wilson disease), lungs disorders (asthma, chronic bronchitis, emphysema, cystic fibrosis, and pneumonia), and many immune system related disorders. In addition, this novel test formulation can also be utilized for organ transplants (i.e., kidney, liver, and heart transplants), hormonal imbalance, aging, and various inflammatory and immune-related disease conditions.

\section{Acknowledgement}

Authors gratefully acknowledged to Trivedi Global, Inc., Trivedi Science, and Trivedi Master Wellness for their support. In addition, authors are thankful for the support of Dabur Research Foundation for conducting this study.

\section{References}

1. WHO (2004) WHO Guidelines on safety monitoring of herbal medicines in pharmacovigilance systems? World Health Organization, Geneva, Switzerland.

2. Bandaranayake WM (2006) Quality control, screening, toxicity, and regulation of herbal drugs, in Modern Phytomedicine. In: Ahmad I, Aqil F, Owais M (Eds.), Turning medicinal plants into drugs, pp. 25-57.

3. Sofowora A, Ogunbodede E, Onayade A (2013) The role and place of medicinal plants in the strategies for disease prevention. Afr J Tradit Complement Altern Med 10(5): 210-229.

4. Sen S, Revival CR (2016) Modernization and integration of Indian traditional herbal medicine in clinical practice: Importance, challenges and future. J Tradit Complement Med 7(2): 234-244.

5. Cannell JJ, Hollis BW (2008) Use of vitamin D in clinical practice. Altern Med Rev J Clin Ther 13(1): 6-20.

6. Allen L, de Benoist B, Dary O, Hurrell R (2006) Guidelines on food fortification with micronutrients. World Health Organization, Geneva, Switzerland.

7. Wallace TC, McBurney M, Fulgoni VLI (2014) Multivitamin/mineral supplement contribution to micronutrient intakes in the United States, J Am Coll Nutr 33(2): 94-102.

8. Yetley EA (2007) Multivitamin and multimineral dietary supplements: Definitions, characterization, bioavailability, and drug interactions. Am J Clin Nutr 85(1): 269S-276S.

9. Mahady GB, Gyllenhall C, Fong HH, Farnsworth NR (2000) Ginsengs: a review of safety and efficacy. Nutr Clin Care 3: 90-101.

10. Attele AS, Wu JA, Yuan CS (1999) Ginseng pharmacology: multiple constituents and multiple actions. Biochem Pharmacol 58(11): 16851693.

11. Czekanska EM, Stoddart MJ, Richards RG, Hayes JS (2012) In search of an osteoblast cell model for in vitro research. Europ Cells Mat 24: 1-17.

12. Schaefer WR, Fischer L, Deppert WR, Hanjalic BA, Seebacher L, et al. (2010) in vitro ishikawa cell test for assessing tissue-specific chemical effects on human endometrium. Reprod Toxicol 30(1): 89-93.

13. Valavanidis A, Vlachogianni T, Fiotakis K, Loridas S (2013) Pulmonary oxidative stress, inflammation and cancer: Respirable particulate matter, fibrous dusts and ozone as major causes of lung carcinogenesis through reactive oxygen species mechanisms. Int J Environ Res Public Health 10(9): 3886-3907.

14. Bouma ME, Rogier E, Verthier N, Labarre C, Feldmann G (1989) Further cellular investigation of the human hepatoblastoma-derived cell line HepG2: Morphology and immunocytochemical studies of hepaticsecreted proteins. in vitro Cell Dev Biol 25(3): 267-75.

15. Bak MJ, Jun M, Jeong WS (2012) Antioxidant and hepatoprotective effects of the red ginseng essential oil in $\mathrm{H}_{2} \mathrm{O}_{2}$-treated HepG2 cells and $\mathrm{CCl}_{4}$-treated mice. Int J Mol Sci 13(2): 2314-2330.

16. Molavi B, Mehta JL (2004) Oxidative stress in cardiovascular disease: Molecular basis of its deleterious effects, its detection, and therapeutic considerations. Curr Opin Cardiol 19(5): 488-493. 
17. Meneses A, Liy-Salmeron G (2012) Serotonin and emotion, learning and memory. Rev Neurosci 23(5-6): 543-553.

18. Rohm B, Holik AK, Somoza MM, Pignitter M, Zaunschirm M, et al. (2013) Nonivamide, a capsaicin analog, increases dopamine and serotonin release in SH-SY5Y cells via a TRPV1-independent pathway. Mol Nutr Food Res 57(11): 2008-2018.

19. Haussler MR, Whitfield GK, Haussler CA, Hsieh JC, Thompson PD, et al. (1998) The nuclear vitamin D receptor: biological and molecular regulatory properties revealed. J Bone Miner Res 13(3): 325-349.

20. Brown AJ, Brown AJ, Slatopolsky E (1999) Vitamin D. Am J Physiol Renal Physiol 277(2): F157-F175.

21. Maizes V, Rakel D, Niemiec C (2009) Integrative medicine and patientcentered care. Explore (NY) 5(5): 277-289.

22. Bischof M, Del Giudice E (2013) Communication and the emergence of collective behavior in living organisms: a quantum approach. Mol Biol Int 2013: 987549.

23. Cassidy CM (2004) What does it mean to practice an energy medicine? J Altern Complement Med 10(1): 79-81.

24. Fan K wai (2005) National center for complementary and alternative medicine website. J Med Libr Assoc 93(3): 410-412.

25. Trivedi MK, Tallapragada RM (2008) A transcendental to changing metal powder characteristics. Met Powder Rep 63(9): 22-28, 31.

26. Trivedi MK, Nayak G, Patil S, Tallapragada RM, Latiyal O (2015) Studies of the atomic and crystalline characteristics of ceramic oxide nano powders after bio field treatment. Ind Eng Manage 4: 161.

27. Trivedi MK, Branton A, Trivedi D, Nayak G, Mondal SC, et al. (2015) Morphological characterization, quality, yield and DNA fingerprinting of biofield energy treated alphonso mango (Mangifera indica L.). Journal of Food and Nutrition Sciences 3(6): 245-250.

28. Trivedi MK, Branton A, Trivedi D, Nayak G, Charan S, et al. (2015) Phenotyping and 16S rDNA analysis after biofield treatment on Citrobacter braakii: A urinary pathogen. J Clin Med Genom 3: 129.

29. Trivedi MK, Patil S, Shettigar H, Mondal SC, Jana S (2015) Evaluation of biofield modality on viral load of Hepatitis B and C viruses. J Antivir Antiretrovir 7: 083-088.

30. Trivedi MK, Patil S, Shettigar H, Bairwa K, Jana S (2015) Phenotypic and biotypic characterization of Klebsiella oxytoca: An impact of biofield treatment. J Microb Biochem Technol 7: 203-206.

31. Nayak G, Altekar N (2015) Effect of biofield treatment on plant growth and adaptation. J Environ Health Sci 1: 1-9.

32. Branton A, Jana S (2017) The influence of energy of consciousness healing treatment on low bioavailable resveratrol in male Sprague Dawley rats. International Journal of Clinical and Developmental Anatomy 3(3): 9-15.

33. Branton A, Jana S (2017) The use of novel and unique biofield energy healing treatment for the improvement of poorly bioavailable compound, berberine in male Sprague Dawley rats. American Journal of Clinical and Experimental Medicine 5(4): 138-144

34. Kinney JP, Trivedi MK, Branton A, Trivedi D, Nayak G, et al. (2017) Overall skin health potential of the biofield energy healing based herbomineral formulation using various skin parameters. American Journal of Life Sciences 5(2): 65-74

35. Singh J, Trivedi MK, Branton A, Trivedi D, Nayak G, et al. (2017) Consciousness energy healing treatment based herbomineral formulation: A safe and effective approach for skin health. American Journal of Pharmacology and Phytotherapy 2(1): 1-10.

36. Trivedi MK, Branton A, Trivedi D, Nayak G, Plikerd WD, et al. (2017) A systematic study of the biofield energy healing treatment on physicochemical, thermal, structural, and behavioral properties of magnesium gluconate. International Journal of Bioorganic Chemistry 2(3): $135-145$
37. Trivedi MK, Patil S, Shettigar H, Mondal SC, Jana S (2015) The potential impact of biofield treatment on human brain tumor cells: A time-lapse video microscopy. J Integr Oncol 4(3): 141.

38. Anagnos D, Trivedi K, Branton A, Trivedi D, Nayak G, et al. (2018) Influence of biofield treated vitamin D3 on proliferation, differentiation, and maturation of bone-related parameters in MG-63 cell-line. International Journal of Biomedical Engineering and Clinical Science 4(1): 6-14.

39. Lee AC, Trivedi K, Branton A, Trivedi D, Nayak G et al. (2018) The potential benefits of biofield energy treated vitamin D3 on bone mineralization in human bone osteosarcoma cells (MG-63). International Journal of Nutrition and Food Sciences 7(1): 30-38.

40. Stutheit ME, Trivedi K, Branton A, Trivedi D, Nayak G, et al. (2018) Biofield energy treated vitamin D3: Therapeutic implication on bone health using osteoblasts cells. American Journal of Life Sciences 6(1): 13-21.

41. Alía M, Ramos S, Mateos R, Bravo L, Goya L (2005) Response of the antioxidant defense system to tert-butyl hydroperoxide and hydrogen peroxide in a human hepatoma cell line (HepG2). J Biochem Mol Toxicol 19(2):119-128.

42. Vargas MN, Madrigal SE, Morales GA, Esquivel SJ, Esquivel CC, et al. (2014) Hepatoprotective effect of silymarin. World J Hepatol 6(3): 144149.

43. Alía M, Ramos S, Mateos R, Bravo L, Goya L (2005) Response of the antioxidant defense system to tert-butyl hydroperoxide and hydrogen peroxide in a human hepatoma cell line (HepG2). J Biochem Mol Toxicol 19(2):119-128.

44. Videla LA (2009) Oxidative stress signaling underlying liver disease and hepatoprotective mechanisms. World J Hepatol 1(1): 72-78.

45. Li S, Tan HY, Wang N, Zhang ZJ, Lao L, et al. (2015) The role of oxidative stress and antioxidants in liver diseases. Int J Mol Sci 16(11): 2608726124.

46. Cheresh P, Kim SJ, Tulasiram S, Kamp DW (2013) Oxidative stress and pulmonary fibrosis. Biochim Biophys Acta 1832(7): 1028-1040.

47. Lu LY, Ou N, Lu QB (2013) Antioxidant induces DNA damage, cell death and mutagenicity in human lung and skin normal cells. Sci Rep 3: 3169.

48. Atkins GJ, Findlay DM, Anderson PH, Morris HA (2011) Vitamin D (3 $3^{\text {rd }}$ edn). Chapter 23-Target Genes: Bone Proteins 1: 411-424.

49. Emami A, Larsson A, Petrén MM, Larsson S (1999) Serum bone markers after intramedullary fixed tibial fractures. Clin Orthop Relat Res 368: 220-229.

50. Burgner JW, Ray WJ (1984) On the origin of the lactate dehydrogenase induced rate effect. Biochemistry 23(16): 3636-3648.

51. Valvona CJ, Fillmore HL, Nunn PB, Pilkington GJ (2016) The regulation and function of lactate dehydrogenase A: Therapeutic potential in brain tumor. Brain Pathol 26(1): 3-17.

52. Kopperschläger G, Kirchberger J (1996) Methods for the separation of lactate dehydrogenases and clinical significance of the enzyme. J Chromatogr B Biomed Appl 684(1-2): 25-49.

53. Pratt DS, Kaplan MM (2000) Evaluation of abnormal liver-enzyme results in asymptomatic patients. N Engl J Med 342(17): 1266-1271.

54. Mathiesen U, Franzen L, Fryden A, Foberg U, Bodemar G (1999) The clinical significance of slightly to moderately increased liver transaminase values in asymptomatic patients. Scand J Gastroenterol 34(1): 85-91.

55. Birben E, Sahiner UM, Sackesen C, Erzurum S, Kalayci O (2012) Oxidative stress and antioxidant defense. World Allergy Organ J 5(1): 9-19.

56. Meltzer CC, Smith G, DeKosky ST, Pollock BG, Mathis CA, et al. (1998) Serotonin in aging, late-life depression, and Alzheimer's disease: the emerging role of functional imaging. Neuropsychopharmacology 18(6): 407-430. 
57. Lin SH, Lee LT, Yang YK (2014) Serotonin and mental disorders: A concise review on molecular neuroimaging evidence. Clin Psychopharmacol Neurosci 12(3): 196-202.

58. Berger M, Gray JA, Roth BL (2009) The expanded biology of serotonin. Annu Rev Med 60: 355-366.

59. Iqbal N, van Praag HM (1995) The role of serotonin in schizophrenia. Eur Neuropsychopharmacol 5(Suppl): 11-23.
60. Haussler MR, Whitfield GK, Haussler CA, Hsieh JC, Thompson PD, et al. (1998) The nuclear vitamin D receptor: Biological and molecular regulatory properties revealed. J Bone Miner Res 13(3): 325-349.

61. Hollis BW (2005) Circulating 25-hydroxyvitamin D levels indicative of vitamin D sufficiency: implications for establishing a new effective dietary intake recommendation for vitamin D. J Nutr 135(2): 317-322.

62. Carlberg C, Molnár F (2012) Current status of vitamin D signaling and its therapeutic applications. Curr Top Med Chem 12(6): 528-547. 